\title{
Fostering Social Change Through Short Films: How to Train Future Media Professionals in an Interdisciplinary and Applied Way
}

\author{
Jorge Franganillo \\ University of Barcelona \\ Lydia Sánchez \\ University of Barcelona
}

M. Ángeles García Asensio
University of Barcelona

Anna Marquès
University of Barcelona

This paper describes an effective methodological strategy that the Consolidated teaching innovation group in Communication and Audiovisual Media (In-COMAV), composed of a multidisciplinary teaching team, has been developing since 2016 within the Audiovisual Communication degree program offered by the University of Barcelona. This strategy consists of promoting service-learning projects within the context of various courses. Here we present the viability criteria established for the acceptance of projects oriented toward collaboration with organizations outside the university, the critical success factors and the results that this initiative has had on students, teachers, the university and society. Such results are perceived positively, yet there are still challenges and limitations to be overcome to ensure the continuity, sustainability and effectiveness of service-learning projects in higher education.

Keywords: teaching innovation, service learning, interdisciplinary learning, applied learning, audiovisual creation, unfair competition

\section{INTRODUCTION}

As is widely known, universities play a social role. They are regarded as key institutions not only for personal and professional development, but also for promoting social change, so they serve a dual role. First of all, universities provide the professional training for high-level jobs. Secondly, and just as significantly, they train in skills and abilities that allow students to develop values and virtues that can enhance not just individual but also social well-being. Therefore, universities must promote educational innovation initiatives with a social impact, aimed at facilitating competency-based learning.

To achieve these objectives, positive psychology offers teachers a scientific grounding to guide planning of their academic activity. This psychological theory understands human behavior in terms of 
what are referred to as character strengths, proposing six universal categories for classifying such strengths or virtues of an individual's character. These categories are: wisdom and knowledge; courage; humanity; justice; temperance; and transcendence. Based on this classification, individuals - teachers and studentscan identify the strong points of their character and work on them (Peterson and Seligman, 2004).

This study presents a teaching experience that shares some of the assumptions of positive psychology. The human and social sciences are especially appropriate for conceiving of learning from this psychological perspective, as their content, competencies and skills are largely associated with values. In particular, this experience is taking place in the Audiovisual Communication degree program offered by the University of Barcelona's Faculty of Information and Audiovisual Media, whose objective is to train media professionals and content creators with a 4-year curriculum covering various professional profiles: scriptwriter, producer, director, visual and sound post-production designer, researcher and corporate communication specialist.

This degree program is based on a concept of communication that goes beyond its standard definition as the mere transmission of information. Indeed, we question the linear model of communication that has dominated research in this area for decades, and that has also dominated the educational model in general, especially at the university level. One of the consequences arising from this approach is an excessive emphasis on the transmission of content that may not give sufficient attention to values and the emotional education associated with them. Often placed in opposition to the linear model is a model of communication as community: the Latin word communicäre means to share, to create community, and for some authors this is precisely the main function of communication, to establish social connections, and to create a shared culture (Carey, 1989; Craig, 1999). In this sense, values play a primordial role.

\section{IMPROVING AUDIOVISUAL COMMUNICATION STUDENTS' CAREER READINESS}

Based on our understanding of the concept of communication, we hold a firm conviction that teaching and learning processes cannot be articulated around the transmission of content alone, but must also take into account the role of emotions and values in intelligent behavior. With this in mind, for three years now a team of professors, now recognized as a consolidated teaching innovation group in Communication and Audiovisual Media (In-COMAV), have been implementing some ideas to improve the professional preparation of students.

The set of initiatives this team is implementing to improve the career readiness of students includes training them in various forms of persuasive communication, promoting their participation in fiction and documentary film festivals and, more particularly, promoting the development of service-learning projects that combine learning and community service. In short, this team has adopted a pedagogical strategy that is democratic, supportive, cooperative, eminently practical and community based. And it applies this strategy with a methodology that is active, participatory, problem-solving, relational, reflexive, and transformative, aimed at cultivating skills and values that promote the full development of the human being.

Specifically, learning through service-learning projects allows for the consideration of students' character strengths, the social dimension of intelligent behavior and the function of language and rationality as tools for communication and interaction with others. Service learning thus forms part of an innovative movement in education that transcends the educational institution to include the wider community and promote social change. Through service learning, universities can offer their students the opportunity to participate in contexts where their society needs them.

\section{SERVICE LEARNING AND TEACHING PRACTICE}

Our firm commitment to a teaching strategy that incorporates the dimension of emotions and values into university education is increasingly receiving support from the community (Torre and Tejada, 2006). Service learning geared toward this dimension is an innovation that has entered educational institutions in the wake of other notable innovations like the teaching of texts (essays) written by students, specialized seminars and simulations (both computer-based and live). Specifically, it is based on the conviction that teaching cannot be limited to student training in closed classrooms (Rodríguez and Tiana, 2015). Teachers 
need to open the door and explore outside so that students can contribute to meeting the needs of their community and thus help strengthen their vocation.

At the same time, working with a service-learning methodology enhances the vocation of teachers as well. It creates a work structure where teaching staff form part of a cooperative between student, teacher and external social actors that makes them feel more committed to their students, whose activity is having an impact on society because they are engaging with the community as they would in a professional context (Franganillo et al., 2021).

Moreover, the incorporation of a service-learning methodology into teaching not only breaks down the walls around the classroom and allows teachers and students to get more involved in teaching-learning processes, but it also helps break beyond the limits usually associated with specific subjects. In this way, it helps overcome two barriers that are in a way self-imposed by the prevailing habitus in the university tradition, in the curriculum design and assessment methods that we work with (Trigueros, Ribera and Torre, 2011). As a result, the service-learning formula promotes transdisciplinary learning and offers a whole range of educational benefits:

- it contributes to the development of responsible citizens because students get involved in improving a situation in their community;

- it contributes to personal and social growth and development;

- it reinforces active and meaningful learning, as students work in teams and learn to identify needs, to conceptualize, structure, develop and execute projects, and to assess results;

- it promotes communication (creating community) and collaborative work, because each work team, in the pursuit of its objective, can be made up of students from different courses and different programs, and even from different fields of learning, all in interaction with teachers and social actors external to the university.

In other words, service learning makes use of the strengths and the potential of students, enhances their vocation by getting them working, reinforces their tacit knowledge, creates community (Martínez Usarralde, 2014), and ultimately has an impact on the levels of happiness among students, teachers and society as a whole. In addition, it promotes teaching innovation and the search for effective alternatives to enrich and expand the university teaching model so that students receive a solid education with the knowledge, skills, values and attitudes they need to integrate successfully into the working world.

In short, service learning leaves behind the traditional, teacher-focused university education approach oriented toward lectures, memorizing information, and individual student work. It even goes beyond the active learning or knowledge-building methods (pragmatic social constructivism) that aim to bring the learning experience closer to reality by simulating real-life situations for knowledge application and skill development, and through role playing, case studies, or problem solving (Jenaro et al., 2013). Service learning does not make use of these simulation strategies but takes students - and teachers - into the real world, to deal with real needs that demand viable and effective solutions.

In this way, service learning is in line with other active methodologies like challenge-based learning (Observatorio de Innovación Educativa, 2016), which also encourage students to get involved in researching and acting in a real-life environment, to connect different knowledge areas and to create contexts for reflection on their learning. With these approaches it shares the fact that the real agent in the process is the learner, with his or her own personality traits and character strengths; but it is also the teacher, who takes a leading role when the emphasis is placed more on a partnership with the students than on grades, and on the teacher's activity as a guide who supports student decisions and accompanies them in the creation of the cognitive structures and mental maps needed to analyze and understand reality and to engage in critical and complex thinking (Karabenick and Collins-Eaglin, 1997). Evidence suggests that the promotion of this kind of collaborative learning is useful for promoting prosocial behaviors among university students (Jenaro et al., 2013). In any case, in contrast with challenge-based learning or other active methodologies, service learning is always attentive to its commitment to society and to community care (Tapia, 2018; Escofet and Fuertes, 2018). In this type of learning, social actors are also key players. 


\section{APPLICATION OF SERVICE-LEARNING METHODOLOGY IN AUDIOVISUAL COMMUNICATION}

The main innovation of service-learning lies in developing a well-articulated, coherent and original educational activity in which the pedagogical purpose is combined with solidarity (Puig et al., 2007; Martínez, 2009). As a methodological approach, service-learning makes the point that teaching cannot be limited to training students while locked in a classroom (Rodríguez and Tiana, 2015).

In the context of the Audiovisual Communication degree, service-learning projects involve the production and direction of a short film with a clear social benefit. These projects therefore have a professionalizing role, as participating students are trained while working to meet real needs in their environment. They also promote knowledge transfer and interdisciplinary work, since students cooperate with professionals from different disciplines (historians, physicians, librarians, etc.).

In the last three years, nine projects have been completed, and three new ones have been launched, involving a total of 50 students and 12 professors. This has meant collaborating with three other faculties and five other institutions (including hospitals, professional societies and neighborhood associations):

- Barcelona School of Nautical Studies, Polytechnic University of Catalonia

- Faculty of Medicine and Health Sciences, University of Barcelona

- School of Nursing, University of Barcelona

- Maritime Museum of Barcelona

- Language Services, University of Barcelona

- Official Association of Librarians-Documentalists of Catalonia

- Popular Historical Archive of Camp de la Bota and La Mina

- Podiatry Hospital, University of Barcelona

Altogether, these projects meet a variety of social needs: some of them seek to raise awareness about compliance with medical therapies, or against self-medication, others relate to coping strategies within a disadvantaged neighborhood, and others aim at disseminating local language and culture, just to mention a few.

Regardless of the topic covered, these projects share a common trait: all of them have been triggered by external proponents, although they have been submitted to a selection committee since not every proposal for collaboration could be accepted. Some of them lacked the social commitment and formative spirit necessary to fit into the educational model of service-learning.

\section{SERVICE-LEARNING PROJECT REQUIREMENTS}

Proponents' requests often sound like a job offers without a salary. From what we have observed, such predatory behavior, seeking out free labor, is widespread. We therefore needed to ascertain some objective facts to decide on what was feasible (and what was not) before involving students and teachers in a new project. To this end, a set of guidelines was developed, first, to identify which proposals have real educational potential, and second, to avoid unfair competition with media professionals: in no case can any project ever replace the provision of a professional service

This set of guidelines has proven useful for identifying what can (and what shouldn't) become a servicelearning project and who can be a recipient of the service. In this sense, it might also be considered a compendium of best practices.

\section{What a Service-Learning Project Must Have}

- Value from an academic perspective. The initiative must have a pedagogical value and must facilitate the development of the specific and cross-cutting skills that the degree aims to confer.

- Social, political, cultural or economic impact. The resulting product must achieve something of public value; it must have some social, political, cultural or economic impact and must have the endorsement of a public institution, a social entity or an organization. 
- Status as a teaching innovation project or a knowledge transfer project, which also means that students need to be provided with a training program.

- Natural development within the framework of a course, from both an academic and a chronological point of view (one academic semester or, only in exceptional cases, one academic year), with a professor who will act as mentor, guiding the students on their learning path.

- A proponent who is prepared to provide some funding, if necessary. On one hand, media schools are not production companies and shouldn't act as if they were. On the other, students should not be required to cover any expenses whatsoever. If there is the need to rent specific equipment, the proponent should cover the expenses. After all, the proponent is the project beneficiary.

\section{What a Service-Learning Project Is Not}

- Work without salary. It should be clear that a service-learning project is not a job assignment. Students should not have to "respond to the proponent's orders." Even if they are working with a "client", it is still an academic project, not a business relationship. Students must conceptualize the product and do some research on the work to be carried out; they must play a leading role in the design of the product.

- A platform for commercial benefit. The product cannot be intended for any kind of promotion or economic benefit. It cannot be an advertisement or a promotional video. Even if there is no profit involved, the product cannot be intended for the sole benefit of the proponent. If the project is internal to the university, there is an appropriate formula: scholarships. In every project, students should get some benefit in terms of curriculum or experience. Even the media school itself could benefit in terms of brand enhancement.

- Unfair competition. The students' activity should not result in unfair competition with media professionals. The proponent should be aware that students are, after all, pursuing a learning activity within the framework of their education, so they may make mistakes and the final product might not be entirely satisfactory. Of course, the university will always ensure the quality of service but in no case should it be committed to providing a professional service. In any case, having this point stated in the guidelines is a protection for teachers and students. It should be borne in mind that most projects involve an investment of money, which would justify a complaint if the result is not fully satisfactory.

\section{METHODOLOGICAL ADVANTAGES, LIMITATIONS, AND IMPLICATIONS}

This initiative has an innovative approach as it emphasizes interdisciplinarity:

- The scope is encyclopedic, as the topics covered are widely varied. Normally, teaching innovation is focused on the discipline itself: nursing studies deals with nursing issues; architecture studies with architectural issues, etc. As teachers of Audiovisual Communication, we need to be open to all fields of knowledge.

- Participating teachers belong to varied areas of knowledge, so if we want to work on persuasive communication, we are not limited to oral communication, but also consider written and online communication, which involves personal branding and other issues.

- Participating students may come from different degree programs and work together on a joint project. In such cases, they are assessed using both joint and separate evaluation rubrics. The joint criteria are those related to the project development (cross-cutting skills), while the separate criteria are those associated with the specific skills of their corresponding degree programs.

- This methodology breaks out of the limits typically associated with specific courses: it breaks down the classroom walls and forces students (and also teachers) to engage in different 
disciplines and to engage in dialogue with external agents, which is inherent to working in the media industry.

However, it is important to note that the implementation of service-learning projects in this specific context is usually the result of partnership proposals received from external actors. The demand is so high that it prevents the establishment of a systematic diagnostic of the environment and its needs. Instead, the selection of projects has most often been based on a detailed evaluation of the proposals received. This evaluation is normally followed by an interview with a representative of the promoting entity to determine, in accordance with the guidelines described above, whether the proposal meets the necessary conditions, whether it is compatible with the service-learning model and whether it is necessary to adjust the objectives or scope of the project to make it viable.

If the conditions are met and there are students interested in getting involved in the project and a teacher available to supervise it, a partnership agreement is signed and a requirement is established that the title credits of the final product must include a reference to the participation of the university. The promoting entity takes part in the development of the project, with a voice to decide on the suitability of the audiovisual product that results from it, assessing the product and often organizing some kind of event to present it publicly. The same entity is then responsible for disseminating the product via channels as diverse as its website or a public hospital waiting room.

The faculty also evaluates the project. The students have to defend the viability and relevance of their work to a panel of teachers that assesses their persuasive oral communication skills. Moreover, after receiving a final grade, the next step is for the students to disseminate their projects and audiovisual products at national and international conferences related to innovation in university education or the dissemination of expert or scientific knowledge. In this way, they also develop persuasive communication skills not only in academic environments but also in scientific and professional contexts.

This means that service learning projects necessarily run longer than an academic term, that students and teachers need to seek sources of funding to attend these conferences (e.g. a private company has been secured to fund the participation of four students at a pharmacology conference in the United States), and that the students continue learning without receiving a grade on their academic record for it; their reward is the learning experience itself. Students who have participated in service learning projects also offer guidance to other students who are just beginning such projects.

Furthermore, the positive response to the resulting audiovisual productions in the environments where they are used has helped earn the loyalty of the entities that promote service-learning projects. For example, there are currently plans for a joint research project with one of the hospitals that has been collaborating on these projects, which will also involve student participation, to measure the impact of the messages disseminated by the audiovisual productions on the level of compliance with the treatments indicated to patients who wait in the waiting rooms where the videos are shown.

\section{RESULTS}

The results observed suggest a marked increase in students' enthusiasm and motivation. Students who participate in these initiatives are aware that the projects they carry out have a social utility and are used in communication campaigns. They perceive learning in an applied, practical way, which is more fun and motivating than ordinary exercises. Since they have to negotiate with a "client" (the proponent) to assess and determine what is really needed, they learn to analyze context, to formulate objectives, to break down complex situations and to design action plans.

In this way, students develop both social and professional skills. Also, as these projects are developed in the field of Audiovisual Communication, students have to build work teams covering all the usual profiles present on a professional film crew. This provides a valuable opportunity to learn role-oriented skills in a real working environment and to develop an aptitude for teamwork. As a side benefit, students participating in this type of initiative tend to earn higher grades (see Table 1). Furthermore, sometimes they are even willing to continue working on the same project after graduating, as has already been observed by other authors (Einfeld and Collins, 2008). 
TABLE 1

GRADES EARNED IN SERVICE-LEARNING (SL) AND NON-SL PROJECTS

\begin{tabular}{lcccc}
\hline \multicolumn{2}{c}{ Course, academic year } & SL projects & SL projects avg. grade & Non-SL projects avg. grade \\
\hline Project II & $2016-17$ & 2 & 9.10 & 7.56 \\
Project II & $2017-18$ & 1 & 8.04 & 6.83 \\
Final Project & $2017-18$ & 2 & 8.40 & 7.48 \\
Project II & $2018-19$ & 1 & 7.31 & 7.35 \\
Final Project & $2018-19$ & 2 & 7.37 & 7.65 \\
Idea to Screen & $2019-20$ & 1 & 9.00 & 7.19 \\
\hline \multicolumn{2}{l}{} & 9 & 8.20 & 7.34 \\
\hline
\end{tabular}

Source: Franganillo et al. (2021)

The teachers appreciate the students' satisfaction with the work done. The excitement and engagement with which they present their work in the oral defenses is notable: they work in teams, like a finely tuned machine, mutually supporting one another.

\section{KEYS TO SUCCESS}

So far, this experience has allowed us to identify some keys to the success of service-learning initiatives:

- Planning and control. If a media school wants to engage in service-learning projects, it should do it gradually to make innovation sustainable and to guarantee its continuity. Developing service-learning projects needs an effective infrastructure. It is wiser to begin with a single project, even a large one, and complete it, than to start many small projects at once and end up not completing any. Also, the burden of management is multiplied with each new project, which is reason enough to focus on a few good projects, or only one, rather than spreading the resources out too thin.

- Receptivity. From inside the university it is sometimes hard to know all the needs of the outside world. In order to identify them, an exercise in humility is needed. The university must listen to the outside world and understand its particular needs, not to impose solutions, but to find a way to help solve problems. The university should not be working for external agents, but with them, as equals (those agents being, for instance, another faculty, a neighborhood or a medical department).

- Collaborative benefit. In this context of collaboration, all parties should win, and the benefit to be provided to each party has to be clearly defined from the start. First of all, the external agent wins because they are benefiting from this initiative. Students should get some benefit (learning, experience, personal growth) and should not be used as free labor. Moreover, their creations can be disseminated in different media and as such should be a valuable contribution to their CVs. Teachers get out of the classroom, negotiate with a "client" and guide the students in a professional context. Finally, by promoting service learning, the university is developing new forms of training that are valuable in multiple ways.

- Rigor. Students do their part to face challenges and overcome problems, and they therefore should be trusted. However, this trust must be accompanied by rigor: their learning must be connected to the courses of their degree program and must also have clearly defined objectives and appropriate assessment procedures.

\section{CONCLUSION}

This experience with service-learning projects has allowed us to establish a set of useful guidelines for identifying collaboration proposals with educational value for Audiovisual Communication students. It is 
our belief that these guidelines can be equally applied to other disciplines as well, as they characterize what service-learning projects are really all about. On the other hand, the methodological advantages offered by these initiatives as teaching and learning experiences cannot be overemphasized: service-learning projects are conceived and developed in complex, real-life situations that demand interdisciplinarity and teamwork.

In this context of collaboration, one positive aspect deserves to be underlined: service-learning is beneficial for all parties involved. Students learn to apply their knowledge: they solve real problems and also develop entrepreneurial and other skills. Teachers, for their part, can reinforce interdisciplinary work and academic coordination. University departments achieve greater institutional outreach by incorporating social engagement into their brand image and highlighting the relationship between knowledge and social welfare. Finally, society is another major beneficiary, since the university gives back to society just what is expected from it: the training of individuals who will contribute to collective well-being.

The results achieved show that students involved in service-learning projects are highly motivated and enthusiastic, as they are aware of the real social impact of their efforts. Students also benefit from applying social and professional skills in a way that is not possible in the closed context of the classroom.

Universities need to develop their capacity for establishing relationships with community partners, and to contribute to the conception and design of partnership projects as an experience that can contribute to skills-based and experiential learning. The emphasis that positive psychology places on emotional intelligence, character strengths, tacit knowledge and the variables that form part of student happiness and well-being is extremely useful for changing the way we think about teaching, learning processes and the role of the university in society.

In fact, universities are very much aware of the value of social engagement, and they are already looking for ways to incorporate this dimension into higher education (Arroyo, 2019). Such social engagement can be stated in the European diploma supplement, but to guarantee its sustainability as an educational practice, teachers who mentor service-learning projects also deserve recognition, since extra effort is needed to provide the personalized attention these projects require. This remains a challenge to be overcome in the future.

\section{REFERENCES}

Arroyo, J. (2019, October 14). Un currículum más allá del aula. El País. Retrieved from https://elpais.com/sociedad/2019/10/13/actualidad/1570981445_198065.html

Einfeld, E., \& Collins, D. (2008). The relationships between service-learning, social justice, multicultural competence, and civic engagement. Journal of College Student Development, 49, 95-109. https://doi.org/10.1353/csd.2008.0017

Escofet, A., \& Fuertes, M.T. (Ed.). (2018). Construint vincles entre universitat i societat. Barcelona: Universitat de Barcelona.

Franganillo, J., Sánchez, L., García, M.A., \& Marquès, A. (2021, in press). Aprendizaje emocional y de valores en la formación universitaria, aplicado al grado de Comunicación Audiovisual de la Universidad de Barcelona. Revista Latina de Comunicación Social, 77.

Jenaro, C., Flores, N., Poy, R., González-Gil, F., \& Martín-Pastor, E. (2013). Metodologías docentes en la educación superior: percepciones del profesorado sobre su importancia y uso. Revista de Enseñanza Universitaria, 39, 1-16. Retrieved from http://institucional.us.es/revistas/universitaria/39/art_2.pdf

Karabenick, S.A., \& Collins-Eaglin, J. (1997). Relation of perceived instructional goals and incentives to college students' use of learning strategies. Journal of Experimental Education, 65(4), 331-341.

Martínez Usarralde, M.J. (2014). Otras metodologías son posibles... y necesarias: cuando la cooperación al desarrollo encontró al ApS (aprendizaje servicio). In Universidad y cooperación al desarrollo: contribuciones de las universidades al desarrollo humano (pp. 135-153). Valencia: Universitat Politècnica. Retrieved from https://www.uv.es/aps/doc/Libros/2016-4.pdf 
Martínez, M. (2009). Aprenentatge servei i construcció de ciutadania activa a la universitat: la dimensió social i cívica dels aprenentatges acadèmics a la universitat. In M. Martínez (Ed.), Aprenentatge servei i responsabilitat social de les universitats. Barcelona: Octaedro.

Observatorio de Innovación Educativa. (2016). Aprendizaje basado en retos. Monterrey: Instituto Tecnológico y de Estudios Superiores de Monterrey. Retrieved from https://observatorio.tec.mx/edutrendsabr

Peterson, C., \& Seligman, M.E.P. (2004). Character strengths and virtues: a handbook and classification. New York: Oxford University Press; Washington, DC: American Psychological Association.

Puig, J.M., Batlle, R., Bosch, C., \& Palos, C. (2007). Aprendizaje servicio: educar para la ciudadanía. Barcelona: Octaedro.

Rodríguez, A., \& Tiana, A. (2015, June-September). Educación superior: mutación digital. Telos: Cuadernos de Comunicación e Innovación, 101, 48-51.

Tapia, M.N. (2018). El compromiso social en el currículo de la Educación Superior. Buenos Aires: CLAYSS.

Torre, S., \& Tejada, J. (2006). La dimensión emocional en la formación universitaria. Profesorado: Revista de Currículum y Formación del Profesorado, 10(2), 1-21.

Trigueros, C., Rivera, E., \& Torre, E. (2011). La evaluación en el aula universitaria: del examen tradicional a la autoevaluación. Revista Internacional de Medicina y Ciencias de la Actividad Física y el Deporte, 12(47), 473-491. Retrieved from

http://cdeporte.rediris.es/revista/revista47/artevaluacion303.htm 